\title{
OPTIMIZATION AND QUERCETIN RELEASE TEST OF MORINGA LEAF EXTRACT (MORINGA OLEIFERA) IN GEL-MICROEMULSION PREPARATION
}

\author{
Weka Sidha Bhagawan*, Ria Ramadhani Dwi Atmaja, Sri Nur Atiqah \\ Department of Pharmacy UIN Maulana Malik Ibrahim Malang \\ Jl. Raya Dadaprejo No.1, Dadaprejo, Junrejo, Batu City, East Java 65233 \\ * Corresponding author: wekabhagawan@farmasi.uin-malang.ac.id \\ Co-author 1: ria.ramadhani85@yahoo.com \\ Co-author 2: atiqoh11@gmail.com
}

\begin{abstract}
Quercetin is a flavonoid compound of the flavonol group that has various biological activities for health. Moringa leaf is one of the plants rich in quercetin which is about $384.61 \mathrm{mg} / 100 \mathrm{~g}$. Quercetin is practically insoluble $(4.5 \mu \mathrm{g} / \mathrm{mL})$. To increase the solubility and release of quercetin microemulsion may be used as Drug Delivery Systems formulated with gels for transdermal use.

The aim of this research is to obtain optimum combination formulation of surfactant (tween 80): cosurfactant (propylene glycol) to form optimal microemulsion system, to find out the characteristics of the preparation and to find out the rate of quercetin release of Moringa leaf extract (M. oliefera) in a gel-microemulsion preparation compared with a control gel (without microemulsion) using an HPMC (Hydroxypropyl methylcellulose) gel basis.

The result shows that optimal concentration tween 80 comparison : propylene glycol to form optimal microemulsion system up to 30\%: $20 \%$ with VCO (virgin coconut oil) oil phase $5 \%$. The characteristics observed including organoleptic, $\mathrm{pH}$, viscosity, and stability are showing optimal condition. The average of quercetin content in gel-microemulsion preparation was $2,22 \pm 0,077 \mathrm{ppm}$ and on control gel was $2.37 \pm 0.042 \mathrm{ppm}$. Quercetin release test using Franz diffusion cell using cellophane membrane, saline phosphate buffer $\mathrm{pH} 7,4 \pm 0,05$ and temperature $37 \pm 0,5{ }^{\circ} \mathrm{C}$ for 6 hours. The average quercetin release flux in the gel-microemulsion preparation was $9.436 \pm 1.178(\mu \mathrm{g} / \mathrm{cm}$ $\left.2 / \mathrm{min}^{1 / 2}\right)$ and the control gel was $5,816 \pm 0.485\left(\mu \mathrm{g} / \mathrm{cm}^{2} / \mathrm{min}^{1 / 2}\right)$. Based on these results it can concluded that the microemulsion gel preparation gives significant difference of quercetin flux rate compared with gel preparation.
\end{abstract}

Keywords: Quercetin, Gel-Microemulsion, quercetin release, moringa leaf extract (Moringa oliefera)

\section{INTRODUCTION}

Moringa plant (Moringa oleifera) is one of the plants that can be used as medicine. Various types of flavonoid compounds in the form of pure compounds such as quercetin, koamferol, luetiolin and others have been widely isolated from this plant. Based on research conducted by Rahmat [1] mentioned that the content of quercetin on moringa leaf of $384,61 \mathrm{mg} / 100 \mathrm{~g}$.

On oral administration of quercetin has a low bioavability in the body where limited absorption and rapid elimination and are metabolized widely in stage II and reabsorbed in the small intestine approximately $20-25 \%$ of the given dose. Therefore, quercetin extract of Moringa leaf is formulated in transdermal preparations to improve its bioavability $[2,3]$.

One of the factors affecting trasdermal drug release is solubility. Quercetin is a hydrophobic compound and is classified in the Bhioparmaceutical Classification System (BCS) II which means quercetin has high permeability but low solubility [4]. Quercetin is practically insoluble $(4.5 \mu \mathrm{g} / \mathrm{mL})$ so there is an attempt to increase the solubility and dissolution rate of quercetin [5]. One way to increase the solubility and release of quercetin can be used microemulsions as drug delivery systems.

J. Islamic Pharm., an open access journal ISSN : 2527-6123 
Microemulsions are a dispersion system developed from emulsion preparations. The advantages of microemulsion preparations compared with conventional emulsions are microemulsion preparations that are thermodynamically stable, clear, transparent, have a very small globule size of 0.1-1.0 $\mu \mathrm{m}$ and have a high solubilization rate that can increase the bioavability of drugs in the body $[6,7]$. Generally the microemulsion system has a low viscosity so that the less suitable used as transdermal preparation.. Therefore, a microemulsion system is added with a gelling agent (HPMC) to increase the viscosity so that transdermal microemulsion system is more convenient to use.

\section{METHODS}

\subsection{Material}

Standard Quercetin (sigma aldirich), Moringa oleifra Leaves from UPT.Materia Medica Batu, Ethanol technical 96\% (PT Panadia), Ethanol 96\% (CV Amani media from LIPI Bogor), Tween 80 (PT Panadia), Propylenglycol (Panadia), HPMC, Potassium Hydrogen Phosphate (CV Amani Media), Sodium Hydroxide (CV Amani Media), Nipagin, Nipasol, Methylene Blue (CV: Amanimedia), Virgin Coconut Oil Oil (VCO) from CV . Herba Bagoes Malang.

\subsection{Instrumentation}

Analytical Balance 210-LC (ADAM), Oven (Memment), UV-Vis Spectrophotometer (Shimadzu 1601), particle size analyzer (Malvern), Rotary Evaporator, VD-1 cone and plane viscometer, Magnetic Stirer (IKA), Hoteplate ( Omni-Multimix Inc), pH Meter 510 (Eutech Instrument), Refrigerator (LG), Franz Diffraction Cell (ITB Glass Workshop), Spuit $5 \mathrm{~mL}$ (Terumo), $250 \mathrm{~mL}$ Beaker Glas (Pyrex), $250 \mathrm{~mL}$ Measuring Glass (Pyrex), Erlenmeyer $500 \mathrm{~mL}$ (Pyrex), Watch Glass, Mortal And Stemper, Funnel, Glass Bottle.

\subsection{Procedures of Research}

\subsection{1_Measurement Moisture Content}

Measurement moisture content of simplicia using moisture analyzer. As much as \pm 0.5 gram sample is inserted in aluminum pan out the sample above pan and then the appliance is closed. The instrument will heat the sample until it shows a constant reading of the water content of the sample $( \pm$ 3-5 minutes).

\subsubsection{Manufacture of Moringa Leaf Extract}

Simplicia Moringa leaf extraction process using ultrasonic maseration method. The simplicia as much as 250 grams in maceration with $96 \%$ ethanol solvent as much as 2.5 liters (1:10) for 24 hours. Furthermore, the maceration process was continued by ultrasonication for 2 min with 3 repetitions on each sample which was inserted and concentrated using rotary evaporator at $60{ }^{\circ} \mathrm{c}$.

\subsubsection{Optimization Microemulsion System}

The preparation of microemulsion is a mixture of water and tweens as the water phase in erlenmeyer. Then propylenglycol, VCO oil and extract $(0.5$ gram $/ 1 \mathrm{~mL}$ of ethanolmixed as the oil phase. The oil phase is put into the water phase slowly and stirred using a magnetic strirer at 1500 rpm for 30 minutes at $35^{\circ} \mathrm{C}$. Formula of microemulsion can be seen in table 1 .

\subsubsection{Gel-Microemulsions Preparation}

The microemulsion gel was prepared by mixing the $80 \%$ microemulsion system into the HPMC gel base as much as $20 \%$ and stirring using a magnetic stirrer at $100 \mathrm{rpm}$ for $15 \mathrm{~min}$ until homogeneous.

J. Islamic Pharm., an open access journal ISSN : 2527-6123 


\subsubsection{Gel Preparation}

The gel base was prepared developing HPMC into $\mathrm{CO}_{2}$ free water for \pm 30 minutes. Methyl paraben and propyl paraben are dissolved in propylene glycol, then added extract of moringa leaf (mixture 1). Mixture 1 is added to the expanding HPMC with stirring until homogeneous.

\subsection{Characteristics of preparations}

\subsubsection{Microemulsion Particle Size Test}

Particle size testing using partcle size analyzer. $1 \mathrm{~mL}$ microemulsion preparation is diluted to $50 \mathrm{~mL}$ of aquadest. A total of $3 \mathrm{~mL}$ of mixture is fed into the cuvette and the instrument will measure particle size and its distribution $\pm 15 \mathrm{~min}$.

\subsubsection{Emulsion Type Test}

The microemulsion type examination is performed by sprinkling a water-soluble methylene blue dye on the surface of the dye on the glass of the object and observed under an optical microscope.

\subsubsection{Organoleptic Test}

The preparations are observed visually against changes in shape, color and odor.

\subsection{4 pH Test}

The preparations of \pm 5 grams measured $\mathrm{pH}$ using $\mathrm{pH}$ meters. The digital $\mathrm{pH}$ meter is immersed in a preparation up to a $\mathrm{pH}$ meter showing a stable number.

\subsubsection{Freeze Thaw Stability Test}

The preparation of \pm 3 grams was tested for stability being alternately stored at cold temperatures $\left(4 \pm 2^{\circ} \mathrm{c}\right) 12$ hours heat temparetur $40^{\circ} \mathrm{C}$ for 12 hours. This process is counted one cycle. Testing is done as many as 7 cycles

\subsubsection{Viscosity Test}

Measurements viscosity use Viscometer cone and plane. \pm 2 grams of preparation were included in the viscometer and measured from 0.5 to $100 \mathrm{rpm}$. Viscosity results are seen when the reading is stable. Viscosity reading is done at every speed. The data obtained are speed (rpm), viscosity (cps), and torque (\%).

\subsubsection{Test of Quercetin Concentration}

Weighed as much as $1 \mathrm{~g}$ preparation and put into a $100 \mathrm{ml}$ measuring flask and then diluted with ethanol to the boundary marker. The solution is pelleted as $1 \mathrm{~mL}$ and then put in a $10 \mathrm{~mL}$ measuring flask and filled to the limit. The solution was measured uptake using UV-Vis spectrophotometry at a wavelength of $373 \mathrm{~nm}$. The qurcetin content in the preparation was calculated using the linear regression quercetin equation in $96 \%$ ethanol $y=0.027 x+0.009$.

\subsection{Release Test}

\section{Cellophane Membrane Preparation}

The diffusion membranes used are Cellophane membranes. The cellophane membrane is cut according to disk size then soaked using aquadest for 1 night. Just before use, the membrane is drained until no water drips.

\section{Franz diffusion cell preparation}

The quercetin release test was carried out using a franz diffusion cell device under the following conditions: The receptor compartment was filled with a phosphate buffer solution of $\mathrm{pH} 7.4$ of about $16 \mathrm{~mL}$ which was maintained at $37 \pm 0.5^{\circ} \mathrm{c}$ and stirred with magnetic stirring at $200 \mathrm{rpm}$. Cellophane membrane is placed between the donor compartment and the receptor compartment. A sample of $1 \mathrm{~g}$ was applied to the membrane surface. Then the samples were taken at 30, 60, 90, 120, 180, 240, 300, $360 \pm 3 \mathrm{~mL}$ minutes from the receptor compartment using syringe and a phosphate buffer solution of

J. Islamic Pharm., an open access journal ISSN : 2527-6123 
pH 7.4 was immediately added to a volume equal to the volume taken. Then, measured uptake at the

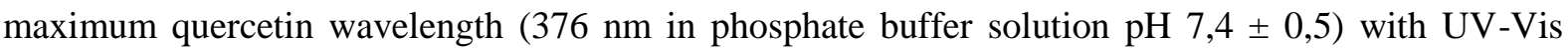
spectrophotometer. The quercetin content read in the release media was calculated using the quercetin linear regression equation in buffer $\mathrm{y}=0.010 \mathrm{x}-0.003$.

To account for the dilution of $3 \mathrm{~mL}$ of release medium. The measured level is corrected by the Wurster equation:

$$
\mathrm{Cn}=\mathrm{C} \text { 'n }+\frac{V s}{V m} \sum_{\mathrm{s}-1}^{\mathrm{N}-1} C s .
$$

Information :

$\mathrm{Cn}$ : Actual level after corrected (ppm)

C'n: The readable content (the calculation result of the absorbance value of the sample read on the spectrophotometer in ppm

Cs: The readable content of the previous sample

Vs: Sample volume taken

Vm: Media volume

Determination of quercetin flux off the base per unit of membrane area at any time $(\mu \mathrm{g} / \mathrm{cm} 2)$, calculated from the obtained level at any time $(\mu \mathrm{g} / \mathrm{ml})$ plus the Wurster correction factor then multiplied by the amount of media $(16 \mathrm{~mL})$ and then divided by the membrane surface area.

\subsection{Data Analysis}

One of the requirements of the Independent Sample T-test is that the data used must be normal and homogeneous distributed. the Independent Sample T-test was used to determine the efficacy of the test results between the two preparations statistically. Test result data is said to have significance if if value $\mathrm{p}$ value $(<0,05)$. If the value of $\mathrm{p}$ value $(>0,05)$ the data is said test result between the 2 dosages has no statistical significance.

\section{RESULT AND DISCUSSION}

\subsection{Result of moisture content and simplicia extraction}

Rendemen extract of 32,14 gram yield $13 \%$ with average moisture content of moringa leaf equal to $7,9 \pm 0,08 \%$. The result obtained has been in accordance with the BPOM requirement about the water content in the simplicia that is $<10 \%$. Water content in addition to the effect on the shelf life of materials can also affect the extraction process. The lower the moisture content, the easier it is for the solvent to extract the desired active compound component [8].

\subsection{Results of Microemulsion System Optimization.}

Optimization results show that the three formulas provide a clear physical appearance. In the formula I with the use of tween 80: 25: $25 \%$ propylenglycol formed microemulsions with low viscosity and creaming form at the top and microemulsion becomes clear after being silenced overnight. In formula II with the use of tween 80: propylenglycol of 27.5: $22.5 \%$ formed a clear microemulsion and in formula III with the use of tween 80: propylenglycol of 30: $20 \%$ formed clear microemulsion with higher viscosity compared with formula II. The higher the surfactant concentration the lower the surface tension can produce a more stable emulsion. In this study, the creaming formed on formula I with the concentration of tween 80: propylenglycol by 25: $25 \%$ may be caused by low viscosity. according to Viyoch et al., [9] the higher the viscosity of a dosage the dosage becomes more stable because the movement of the particles tends to be so difficult that the creaming rate decreases.

J. Islamic Pharm., an open access journal ISSN : 2527-6123 
According Hendradi (2012) the formation of microemulsion system characterized by microemulsion system that has a clear and transparent appearance. Based on the viscosity produced and the formation of creaming, then the most optimum formula microemulsion is formulated 3 which is then done to test the particle size to know the size of the particles.

\subsection{Results of Characterization preparation}

\subsubsection{Emulsion Type Result}

Based on the results of the test using an optical microscope showed that the microemulsion preparation has a type of oil in water $(\mathrm{m} / \mathrm{a})$. This is because the methylene blue mixed in the microemulsion preparation is evenly dispersed throughout the microemulsion preparation surface. In the microemulsified preparation formulations are used surfactant tween 80 and propylenglycol as cosurfactants with VCO oil phase. Tween 80 is hydrophilic and the concentration of oil in the preparation microemulsion is lower than the water concentration so that the emulsion type produced is oil in water.

\subsubsection{Results of Particle Size}

The particle size test is performed to determine the particle size and its conformity with predetermined standards. According to Harwash [7] the size of microparticles ranges from 0.1 to 1.0 $\mathrm{mm}$. Based on the results of the test, the average particle size of microemulsion of $11.56 \mathrm{~nm}$ or $0.01156 \mu \mathrm{m}$ which is included in the nanoparticle range is between 10-200 $\mathrm{nm}$ [10] Based on the test results, the average value of polydispersity index of microemulsion particle is 0.1553 . The polydispersity index is said to be homogeneous dispersed if the index is at $0.2-0.7$. The polydispersity index value is used to determine the dispersion of globular size and the presence or absence of aggregation. It is said to be monodispersed if the globular size distribution is narrow and has a good degree of homogeneity. The monodispersive system is more stable than the polydispersion system because polydispersion tends to aggregate. Globular aggregation is caused by a polydispersion system which has an opposite charge resulting in an attractive pull between the globules [11].

\subsubsection{Result of Organoleptic Test}

Based on organoleptic test of gel-microemulsion formulation and gel of Moringa leaf extract which is made has the same relative physical characteristics that is gel-shaped, yellowish-green and smelling of extract. Where the results obtained have met the criteria of gel preparation HPMC good. According to Arikumalasari [12] HPMC gel preparations if not added another material is homogeneous, odorless, colorless and transparent ge. Green to yellow color and the smell of extracts in the preparation because the extract of Moringa leaves is yellowish green and has a strong smell of extract.

\subsubsection{Result of pH Test}

Based on the test results obtained $\mathrm{pH}$ preparation gel-microemulsion of $(6.10 \pm 1.00)$ and gel preparation sebsar $(6.10 \pm 1.00)$. The $\mathrm{pH}$ produced from the 2 formulas meets the $\mathrm{pH}$ criteria that can not irritate the skin. According to Handayani [13] Pharmaceutical preparations given either transdermally or topically should meet the skin $\mathrm{pH}$ targetag of $\mathrm{pH} 4.5-6.5$. The preparation should not be too acidic because it can irritate the skin but the preparations should also not be too alkaline because it will make the skin becomes dry. In the resulting $\mathrm{pH}$-gel microemulsion preparations lower than in the gel preparation this is due to the addition of aquadestilata in the gel-microemulsion preparation more than in the gel preparation. This amount of aquadestilata causes more $\mathrm{H}^{+}$groups to cause more acidic $\mathrm{pH}$ values. Therefore, the $\mathrm{pH}$ of the gel-microemulsion preparation is more acidic than the gel preparation [14]. Based on T-test results obtained $p$ value of 0.288 (> 0.05) which means the addition of microemulsion system into gel formula does not give statistically significant $\mathrm{pH}$ effect.

J. Islamic Pharm., an open access journal ISSN : 2527-6123 


\subsubsection{Viscosity Testing}

Viscosity testing is done to know the level of viscosity of the preparation. the viscosity is the resistance of a semisolid preparation to flow or spread. The higher the viscosity the greater flow [15]. According to Garg et al., [16] the viscosity of the gel preparation is either 2000-4000 cps. The results of test for 2 formulas show that the viscosity of the gel preparation has met the criteria of good gel viscosity based on the literature. Based on the indipendent sample T-test results obtained $\mathrm{p}$ value of $0.00(<0.05)$ which means the addition of microemulsion system into the formula gives statistically significant viscosity differences.

\subsubsection{Stove Freeze Thaw Testing}

Based on the results of freeze thaw stability test for 7 cycles showed that the gel-microemulsion and gel preparation was stable at extreme temperature storage indicated by the absence of separation in the preparation.

\subsubsection{Testing of Quercetin Content}

Based on test result of quercetin content in preparation, the result of quercetin content in gelmicroemulsion preparation was $2,22 \pm 0.077$ while in gel preparation was $2,37 \pm 0.042$. The T-test results obtained $\mathrm{p}$ value of $0.168(>0.05)$ which means that the preparation of gel-microemulsion preparation does not give significant difference of quercetin content compared with gel preparation.

\subsubsection{Testing of Quercetin Release}

The last evaluation is the release test. The release test was performed to determine the effect of microemulsion system on quercetin release. The magnitude of the quercetin release rate or flux price is obtained by making a linear regression equation between $t$ roots and the cumulative amount of quercetin that is detached from the base. Result the calculation results, the flux of gel-microemulsion preparation was $9.436 \pm 1.178(\mu \mathrm{g} / \mathrm{cm} 2 / \mathrm{min} 1 / 2)$ and the gel preparation was $5,816 \pm 0.485(\mu \mathrm{g} /$ $\mathrm{cm} 2$ / menit1 / 2). The independent test sample T-test result obtained p value of $0,047(<0,05)$ which gel-microemulsion preparation gives significant difference of quercetin flux rate compared with gel preparation.

According to Williams and Barry [17] there are three main factors that determine the efficacy of transdermal drugs such as drug movement in the carrier, drug release in the carrier, and drug release in the skin. The movement of the drug in the carrier is affected by the viscosity of the preparation. The viscosity of the gel-microemulsion preparation was lower than that of the gel preparation. This is presumably because the movement of quercetin in gel-microemulsions is greater than that of the gel so that quercetin is more easily released. This shows that in this study the viscosity of the dosage influences the release of quercetin extract of moringa leaves from the preparation.

The rate of quercetin release of the gel-microemulsion and gel preparations is also strongly influenced by the affinity of the drug substance with the carrier. Drugs that have a high affinity in the carrier will be difficult to dislodge and go to the absorption site for absorption. Quercetin is a compound that has a lipophilic tendency. consequently, quercetin will have a high affinity with lipophilic ingredients making it difficult to remove from the material. An ingredient if it possesses the same lipophilic and hydrofactic properties will be strongly bonded to each other with the same properties [14].

The gel-microemulsion formula has a higher release flux than the gel formula. This is presumably due to the gel-microemulsion preparations added tween 80 and propylenglycol which serves to increase the solubility of quercetin. In the gel-microemulsion formula used vco oil that is lipofil is a compound that is not water soluble in small quantities while the combination of tween 80 and propylengllikol in large quantities. The high use of a combination of tween 80 and propylene glycol causes the bonding between hydrophilized vco oil to lipophilic quercetin to weaken and

J. Islamic Pharm., an open access journal ISSN : 2527-6123 
quercetin is easily removed from the base. Propylene glycol may increase release because propylenglycol may act as a cosolvent which can increase the solubility of quercetin in order to increase drug release through the membrane. In the gel formula is also used propilenglikol which also serves to increase the solubility of quercetin. However, the propylenglycol used is first mixed in the base. So there is no direct contact between quercetin and propylenglycol so it is suspected that the solubility of quercetin in the gel preparation is low and the rate of quercetin release decreases.

Particle size affects the amount of drug that penetrates the skin. The smaller the size of the particles produced the amount of drug interacting with the area on the stratum corneum increases, thus the number of drugs released is higher [10]. Based on the test results obtained Microemulsion particle size of $11.56 \pm 0.48539 \mathrm{~nm}$ where the size of this particle is smaller than the size of the extract is still micro size or about $\pm>363 \mu \mathrm{m}$ [18]. This shows that in this study particle size significantly influence the release of quercetin extract of moringa leaf from the preparation. With smaller particle sizes, the dosage can provide high absorption efficiency at various delivery routes [12].

\section{CONCLUSIONS}

The optimum formula of microemulsion was obtained from comparison of surfactant and cosurfakktan (tween 80: propylenglycol) by $30 \%$ : $20 \%$ with vco oil phase of $5 \%$. The physical characteristics of the gel-microemulsion indicate that the gel-microemulsion preparation is yellow, gel-shaped and smelling of the extract. The $\mathrm{pH}$ test results of $6.0 \pm 1.0$; viscosity $2,135 \pm 102,2 \mathrm{cps}$, quercetin level 2,22 $\pm 0.077 \mathrm{ppm}$ and stable on freeze thaw stability. The flux-release rate of quercetin flux-gel microemulsion was $9.436 \pm 1.178\left(\mu \mathrm{g} / \mathrm{cm} 2 / \mathrm{min}^{1 / 2}\right)$ higher than that of the conventional gel, at a rate and gel flux of $5,816 \pm 0.485(\mu \mathrm{g} / \mathrm{cm} 2 / \min 1 / 2)$.

\section{SUGGESTIONS}

In the next research is expected to do test the activity of gel-microemulsion preparations as antioxidant activity.

\section{REFERENCES}

[1] Rahmat, H. 2009. Identifikasi Senyawa Flavonoid Pada Sayuran Indigenous Jawa Barat [skripsi]. Bogor: Program Teknologi Pertanian Institut Pertanian Bogor.

[2] Gilley, A.D; Arca, H.C; Nichols, B.I.B dan Giraldo, L.I.M. 2017. Novel cellulose- based amorphous solid dispersion enhance quercetin solution concentrations in vitro. Elseiver. Vol, 157: 89-91.

[3] Tjay, Tan Hoan dan Kirana Rahardja, 2007, Obat-Obat Penting Khasiat, Penggunaan dan Efek-Efek Sampingnya Edisi Keenam. Jakarta: PT. Elex Media Komputindo.

[4 ] Kakran, M; Sahoo, N.G; Lin, L dan Muller R.H. 2011. Comprasiaon Of Homogenization And Precipation Techniques For Production Of Quercetin Nanocyrstal. Cameca Jurnal: 2-9.

[5] Syofyan; Lucida, H dan Bakhtiar, A. 2008. Peningkatan Kelarutan Kuersetin Melalui Pembentukan Kompeks Inklusi Dengan $\beta$-Siklodekstrin. Jurnal Sains Dan Teknologi Farmasi. Vol, 13, No. 2: 43 - 48.

[6] Lawrence, M.J dan Gareth, D. R. 2000. Microemulsion Based Media As Novel Drug Delivery System. Elseiver Advence Druh Delivery Reviews. Vol, 45 (2000): 89-121.

[7] Harwansh, R.K; Rahman, M.A dan Dangi, J.S. 2010 Microemulsion System For Transdermal Delivery Of Diclofenac Soium For Bioavailability Enhancement.Journal Of Pharmacy Research. Vol, 3(9): 21832185.

[8] Hardianti, F. 2015. Pemanfaatan Aktivitas Antioksidan Ekstrak Daun Kelor (Moringa oliefera) Dalam Sediaan Hand and Body Cream [skripsi]. Jakarta: Program Studi Kimia UIN Syarif Hidayatullah.

[9] Viyoch, J.2003. Development of o/w emulsion containing tamarind fruit pulp etxract. Naraseuan University Journal. Vol, 11 (3): 29-49.

J. Islamic Pharm., an open access journal ISSN : 2527-6123 
[10] Pathak, Y dan Thassu, D. 2009. Drug delivery nanoparticle formulation and characterization. New York: Informa Helathcare.

[11] Rahmawanty, D; Anwar, E dan Bahtiar A. 2014. Formulasi Gel Menggunakan Serbuk Daging Ikan Haruan (Channa Striatus) Sebagai Penyembuh Luka. Media Farmasi. Vol, 11(1): 29-40.

[12] Arikumalasari, J; Dewantara, I G.N.A dan Wijayanti, N.P.AD. 2013. Optimasi HPMC Sebagai Gelling Agent Dalam Formula Gel Ekstrak Kulit Buah Manggis (Garcinia mangostana L.). Naskah Publikasi: 145-148.

[13] Handayani, D.W; Yusriada dan Hardani.R. 2016. Formulasi Mikroemulsi Ekstrak Terpurifikasi Daun Bayam Merah (Amaranthus TricolorL.) Sebagai Suplemen Antioksidan. Galenika Journal of Pharmacy Vol. 3 (1) : $1-9$

[14] Hendradi, Esti; Purwanti,T Dan Suryanto, Aryco Andy. 2012 Karakterisasi Sediaan Dan Uji Pelepasan Natrium Diklofenak Dengan Sistem Mikroemulsi Dalam Basis Gel HPC-M. Pharmascienta, Vol 1, No 2: 20-24.

[15] Sinko, P.J. 2011. Farmasi Fisik dan Ilmu Farmasetika Edisi 5. Jakarta: EGC Kedokteran.

[16] Garg, A.D; Aggarwal, S.G dan Sigla A.K. 2002. Spreading Of Semisolid Formulation. Pharmaceutical Technology. p: 84- 104.

[17] Williams A.C dan barry B.W. 2004 Penetration Enhancer. Advanced Drug Deliv ery Review. Vol, 26(5): 02-16.

[18] Harmi, Liza. 2014. Pembuatan Nanogingerol Dari Ekstrak Jahe (Zingiber Officinale Rosc) Menggunakan Homogenizer Dengan Kombinasi Inversi Komposisi dan Suhu. Naskah Publikasi Institut Pertanian Bogor, p: 30-39. 
Table 1: Optimatization Formula of Microemulsion Sytem

\begin{tabular}{ccccc}
\hline \multirow{2}{*}{ Bahan } & \multicolumn{3}{c}{ Formula } & Fungsi \\
\cline { 2 - 4 } & F1 & F2 & F3 & \\
\hline Moringa leave extract & $5 \%$ & $5 \%$ & $5 \%$ & Active ingridient \\
\hline Tween 80 & $25 \%$ & $27,5 \%$ & $30 \%$ & surfactant \\
\hline PPG & $25 \%$ & $22,5 \%$ & $20 \%$ & Kosurfactant \\
\hline VCO & $10 \%$ & $10 \%$ & $10 \%$ & Oil phase \\
\hline Water & Add 100 & Add 100 & Add 100 & Water phase \\
\hline
\end{tabular}

Table 2: Formulation of gel-mikroemulsi and gel

\begin{tabular}{cccc}
\hline \multirow{2}{*}{ Material } & \multicolumn{2}{c}{ Formula \% } & Function \\
\cline { 2 - 4 } & $\begin{array}{c}\text { Gel- } \\
\text { microemulsion }\end{array}$ & Gel & Active ingridient \\
\hline Moringa leave extract & - & $5 \%$ & sytem \\
\hline microemulsion & $80 \%$ & $15 \%$ & Gelling agent \\
\hline HPMC & $15 \%$ & $0,1 \%$ & Preservative \\
\hline Nipagin & $0,1 \%$ & $0,01 \%$ & Preservative \\
\hline Nipasol & $0,01 \%$ & $5 \%$ & kosolven \\
\hline Propilen glikol & $5 \%$ & Add & Solvent \\
\hline $\mathrm{CO}_{2}$ free water & Add & &
\end{tabular}

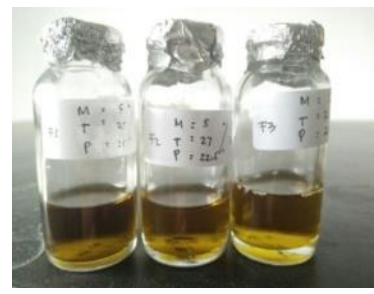

Figure 1:

Sytem Of Microemulsion F1, $\mathrm{F} 2$ and F3

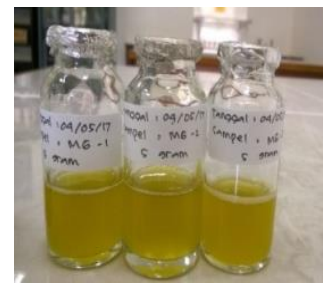

Figure 2:

Gel-Microemulsion Preparation Rep 1, Rep 2, and Rep 3

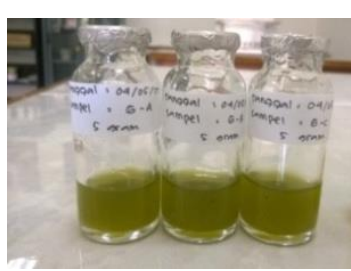

Figure 3:

Gel Preparation Rep 1, Rep 2, and Rep 3

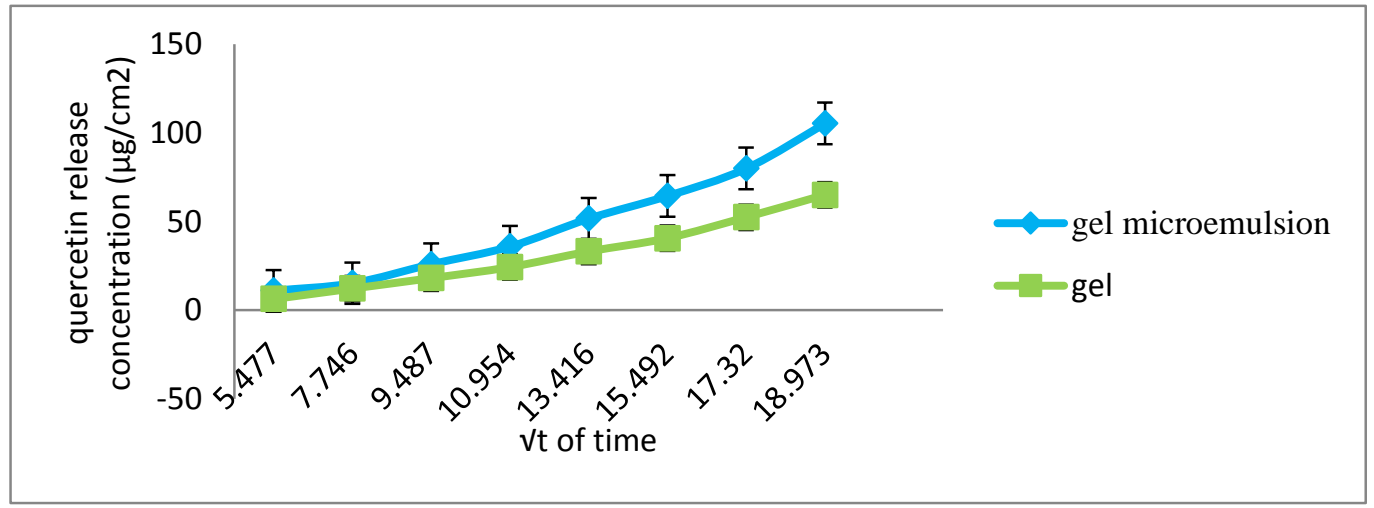

Figure 4: Quercetin Release Profile In Gel-Microemulsion and Gel preparations 